\title{
Plasmonic Photocurrent Improvement in P3HT:PCBM Organic Solar Cells
}

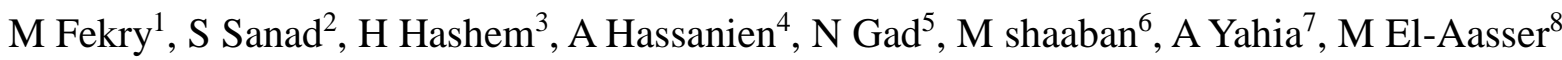 \\ 1* Mathematics Engineering and Physics Department, The Higher Institute of Engineering, Shorouk \\ Academy, El-Shorouk City, Cairo, Egypt and \\ Physics Department, Faculty of Science, Helwan University, Helwan, Egypt \\ (ORCID ID 0000-0002-8432-041X) physicistmahmoudfathy@gmail.com \\ ${ }^{2 *}$ Physics Department, Faculty of Science, Ain Shams University, Cairo 11566, Egypt \\ (ORCID ID 0000-0003-2461-4245) shymaamohamed1994@ gmail.com \\ 3* Physics Department, Faculty of Science, Helwan University, Helwan, Egypt \\ (ORCID ID 0000-0002-8629-2221) hany m hashem@yahoo.com \\ 4* Physics Department, Faculty of Science, Helwan University, Helwan, Egypt \\ (ORCID ID 0000-0002-6690-5721) mu.ibrahim700@gmail.com \\ ${ }^{5 *}$ Physics Department, Faculty of Science, Ain Shams University, Cairo 11566, Egypt \\ (ORCID ID 0000-0002-4175-877X)ngad@ sci.asu.edu.eg \\ 6* Mathematics Engineering and Physics Department, The Higher Institute of Engineering, Shorouk \\ Academy, El-Shorouk City, Cairo, Egypt \\ (ORCID ID 0000-0003-4125-8246)M.shaaban@ sha.edu.eg \\ ${ }^{7 *}$ Physics Department, Faculty of Science, Ain Shams University, Cairo 11566, Egypt \\ (ORCID ID 0000-0003-1998-4647)ayahia@ sci.asu.edu.eg \\ ${ }^{8 *}$ Physics Department, Faculty of Science, Ain Shams University, Cairo 11566, Egypt \\ (ORCID ID 0000-0003-3010-1905) Elaasser@gmail.com
}

(1st International Conference on Applied Engineering and Natural Sciences ICAENS 2021, November 1-3, 2021) (DOI: 10.31590 /ejosat.1022871)

ATIF/REFERENCE: Fekry, M., Sanad, S., Hashem, H., Hassanien, A., Gad, N., shaaban, M., Yahia, A., \& El-Aasser, M. (2021). Plasmonic Photocurrent Improvement in P3HT: PCBM Organic Solar Cells. European Journal of Science and Technology, (28), 1508-1516.

\begin{abstract}
The need to develop and deploy large-scale, cost-effective, renewable energy is becoming tremendously important in the last few decades. Nanostructured organic solar cells have the long-term potential to provide low cost, and high-efficiency renewable energy. In recent years, photovoltaic cells based on nanoparticles blended with semiconducting polymers have achieved good performance and distinguished power conversion efficiencies, greater than $17 \%$. These structures include various sizes and shapes of metal nanoparticles. Intensive research is being done towards achieving organic solar cell efficiency of 20\%. In this work, a detailed numerical simulation is done for a proposed nanostructured organic solar cell design. Different nanoparticle shapes and sizes are considered in the active layer (P3HT:PCBM) to obtain a highly efficient organic solar cell.
\end{abstract}

Keywords: Polymer Solar Cells, Organic Solar Cells, Organic Photovoltaics, Plasmonic Organic Solar Cells.

\section{P3HT:PCBM Organik Güneş Pillerinde Plazmonik Fotoakım İyileştirmesi}

$\ddot{O} z$

Uygun maliyetli, yenilenebilir enerji geliştirme ve dağıtma ihtiyacı, son birkaç on yılda son derece önemli hale geliyor. Nano yapılı organik güneş pilleri, düşük maliyetli ve yüksek verimli yenilenebilir enerji sağlamak için uzun vadeli potansiyele sahiptir. Son yıllarda, yarı iletken polimerlerle harmanlanmış nanoparçacıklara dayalı fotovoltaik hücreler, \%17'den fazla iyi performans ve seçkin güç dönüştürme verimliliği elde etti. Bu yapılar, çeşitli boyut ve şekillerde metal nanoparçacıkları içerir. \%20 organik güneş pili verimi elde etmek için yoğun araştırmalar yapılmaktadır. Bu çalışmada, önerilen bir nanoyapılı organik güneş pili tasarımı için ayrıntılı bir sayısal simülasyon yapılmıştır. Yüksek verimli bir organik güneş pili elde etmek için aktif katmanda (P3HT:PCBM) farklı nanoparçacık şekilleri ve boyutları göz önünde bulundurulur.

Anahtar Kelimeler: Polimer Güneş Pilleri, Organik Güneş Pilleri, Organik Fotovoltaikler, Plazmonik Organik Güneş Pilleri.

*Corresponding Author: physicistmahmoudfathy@gmail.com 


\section{Introduction}

Organic solar cells (OSCs) have turn out to be important class of photovoltaics due to their low cost, small weight, solution processing, wide choice of materials with tunable optical properties and ease of fabrication [1-3]. Small-molecules and solution-processed bulk-heterojunction polymer/fullerene can be used to construct OSCs [4],[5]. Bulk-heterojunction (BHJ) is the active layer that consist of donor and acceptor in one blend [6]. These structures were used for solving the problem of limitations of short exciton lifetime, BHJ improves the charge generation and separation [6],[7]. The active layer P3HT: PCBM blend is sandwiched between Hole transporting layer (HTL), electron transporting layer (ETL), back electrode and semi-transparent front electrode, usually conductive transparent oxide (CTO) ([4],[8],[9]). A power conversion efficiency (PCE) for a conventional BHJ OSC was reported $6.8 \%$ [10]. BHJ OSCs have many problems that make their PCE low, still P3HT:PCBM blend have low absorption due to insufficient light harvesting and short diffusion length of generated excitons in polymer that limit the thickness of active layer $(<100 \mathrm{~nm})$, which make a problem between light absorption and charge collection. Another problem facing OSCs is performance degradation as result of ambient conditions, which effect on efficiency and stability [11-13].

Overcoming these problems by adding noble metal nanoparticles (NPs) with different morphologies and sizes into different layers or different positions into active layer, ETL or HTL with different three mechanisms localized surface Plasmon resonance (LSPR), light scattering, surface Plasmon polariton(s), $\mathrm{SPP}(\mathrm{s})$ to investigate harvesting light and photon management ([14],[15]). The most metal NPs used in BHJ for plasmonic enhancement are silver(Ag) and gold(Au). [16]

Inorganic solar cells achieve high degree of PCE but these solar cells materials are expensive and have complex fabrication techniques. On the other hand, OSCs have many advantages compared to the inorganic solar cells such as low cost, flexibility, light weight, solution processing. unfortunately, OSC has low PCE this is because it has some physical limitations such as small diffusion length of excitons and low carriers' mobility. These limitations lead to use a thin active layer. hence, this results in a low optical absorption and low PCE so, it is important to improve optical absorption to enhance PCE. The most important approach to enhance optical absorption is to trap more light in OSCs.

In this work, the absorption of the active layer of the cell is studied for potential enhancement by adding two-dimensional array of metal NPs with different sizes and shapes. The electromagnetic interaction of the metal electrons and the incident light creates surface wave plasmons that results in trapping the light surrounding the metal NPs. Hence, NPs work as scattering media of light that increases the light paths in the active layer so do the absorption. Hence, the efficiency of the cell increases either.

\section{Device Design and Modeling}

It is very important to simulate any device before fabrication to save time and materials, therefore, the proposed OSC structure is modeled and simulated to predict its optoelectronic properties before fabrication process. The proposed planar structure (without NPs) consists of five layers, $\mathrm{SiO} 2$ layer glass used as a protective layer of $200 \mathrm{~nm}$, Indium tin oxide (ITO) as a front electrode with thickness of $180 \mathrm{~nm}$, PEDOT:PSS as a hole transport layer (HTL) with thickness of $50 \mathrm{~nm}$, then the active layer (P3HT:BCPM) with thickness of $250 \mathrm{~nm}$, then the anode layer of Aluminum (Al) with thickness of $120 \mathrm{~nm}$. The design is shown in Fig 1(a), SiO2/ITO/PEDOT:PSS/P3HT:PCBM/Al. The HTL works as a buffering layer with a band gap of $3 \mathrm{eV}$. The active layer has band gap of $1.7 \mathrm{eV}$ and the work functions of ITO and $\mathrm{Al}$ are 4.7 $\mathrm{eV}$ and $4.2 \mathrm{eV}$ respectively.

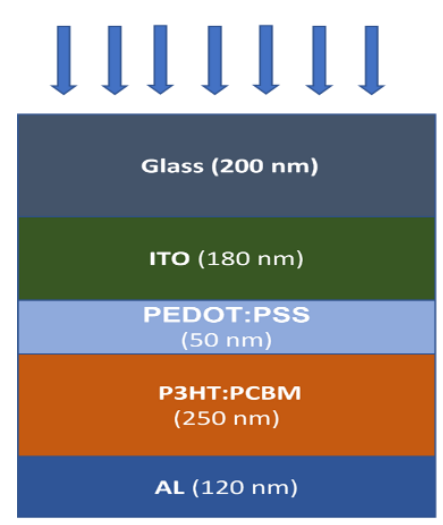

(a)

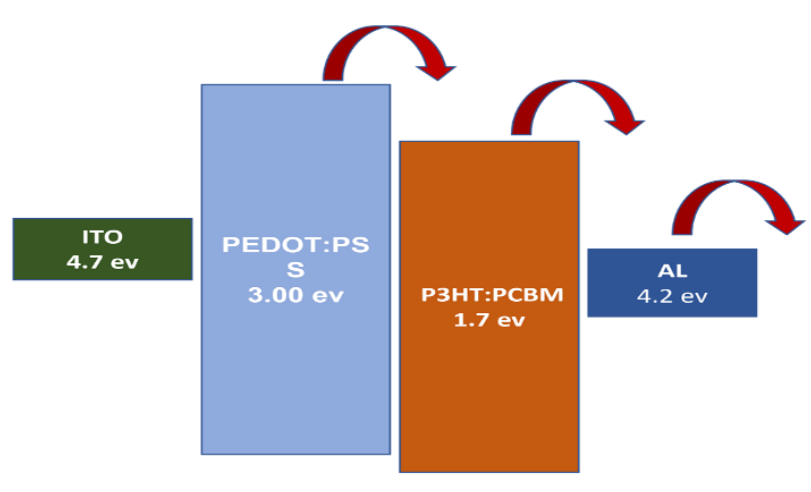

(b)

Fig 1. (a) The proposed OSC design, (b) its energy diagram 
The energy diagram of the planar model, shown in Fig 1(b), shows the transport of charge carrier within the cell.

An in-house tool was used to model the optical simulation which is a three-dimensional finite difference time domain method (FDTD). The incident light source is AM1.5 that directly incident normal to the proposed OSC. The wavelength spans range from 300 to $1100 \mathrm{~nm}$ with step $10 \mathrm{~nm}$. The optical model was used to calculate the active layer absorption spectrum with different structure of the OSC.

The calculations for the proposed OSC structure are made for a unit cell in order to reduce simulation time, the whole OSC is made by repeating these unit cells in both direction $\mathrm{x}$ and $\mathrm{y}$ so we obtain our calculation for this unit cell then generalized the result to whole OSC for any configuration of our OSCs we add a source of plane wave with wavelength range of 300 to 1100 which used to inject sunlight in the $\mathrm{z}$ backward direction. 3DFDTD method is applied to the OSC unit cell with 8 layers as a perfectly matched layer (PML) placed along the $\mathrm{z}$-direction as absorbing boundary at the top and bottom of the device. They were used at the injection direction of light to absorb transmitted and reflected spectrum. The periodic boundary condition in $\mathrm{x}$ direction is set to anti-symmetric and in y-direction to symmetric, with a mesh accuracy value of 2 while a non-uniform conformal mesh was applied to the entire structure. The active layer was surrounded between two FDTD power monitors to calculate the transmittance and reflectance spectra in the active layer. The transmittance monitor was placed at $\mathrm{z}=-450$, the reflectance monitor at $z=-200$, the plane wave source of sunlight at $\mathrm{z}=430$, and the square periodic array of NPs at $\mathrm{z}=-$ 325. The power absorbed was computed using equation (3) from the transmittance and reflectance spectra. The light absorption as function of wavelength is calculated from this relation to calculate light absorption

$$
A(\lambda)=\frac{L(\lambda)}{P_{\text {in }}(\lambda)}
$$

where:

$P_{\text {in }}(\lambda)$ is the power of light incident, $L(\lambda)$ is the power loss by the solar cell, and it is given by

$$
\begin{gathered}
L(\lambda)= \\
-\frac{1}{2} \iiint^{x y z} \operatorname{div}\left\{\operatorname{real}\left(E(x, y, z, \lambda) H(x, y, z, \lambda)^{*}\right)\right\} d x d y d z
\end{gathered}
$$

To calculate the photocurrent density of each model, we first get the absorbed power

$$
P_{a b s}=1-R-T
$$

where $\mathrm{R}$ is the Reflectance and $\mathrm{T}$ is the Transmittance, both are obtained from the FDTD.

Then the Quantum efficiency is computed as

$$
Q E(\lambda)=\frac{P_{a b s}(\lambda)}{P_{\text {in }}(\lambda)}
$$

The integrated quantum efficiency is given by

$$
I Q E=\frac{\int \frac{\lambda}{h c} Q E(\lambda) I_{A M 1.5}(\lambda) d \lambda}{\int \frac{\lambda}{h c} I_{A M 1.5}(\lambda) d \lambda}
$$

where $\mathrm{h}$ is planks constant, $\mathrm{c}$ is the speed of light, $I_{A M 1.5}$ is the AM1.5 standard sunlight incident spectrum, and $\lambda$ is the wavelength.

The photocurrent density is calculated by

$$
J_{s c}=\frac{e}{h c} \int \lambda Q E(\lambda) I_{A M 1.5}(\lambda) d \lambda
$$

The photocurrent density $J_{S c}$ is calculated from equation (6) for each proposed structure and a comparative study is made between them.

\section{Results and Discussion}

In the planner structure, $\mathrm{OSC}(\mathrm{A}), 200 \mathrm{~nm}$ of $\mathrm{SiO} 2$ glass is used as a protective layer to keep our cell away from oxidation and contamination; $180 \mathrm{~nm}$ of ITO which has two purposes, optical purpose as it is anti-reflective material so it will reduce optical loss from reflection and more sun light will enter the cell and not reflected, electrical purpose because of its high electrical conductivity we use it as electrical contact cathode; $50 \mathrm{~nm}$ of PEDOT:PSS as a buffer layer as small thickness of it lead to minimum reflection and hence enhance the optical absorption shown in Fig 2; it also works as broadband layer, $250 \mathrm{~nm}$ of active layer (P3HT:PCBM which have a high absorption coefficient), $120 \mathrm{~nm}$ of $\mathrm{Al}$ layer that reflect sunlight into the upper layer P3HT:PCBM and prevent it from escaping outside OSC so it is effective to enhance the optical absorption. The OSC is assumed to be extended infinitely in both $\mathrm{x}$ and $\mathrm{y}$ directions.

Table 1. shows the photocurrent density $\left(J_{s c}\right)$ for different thickness of PEDOT:PSS layer with constant active layer thickness. It can be noticed that the photocurrent density increases with decreasing the thickness of PEDOT:PSS layer, For PEDOT:PSS thickness $50 \mathrm{~nm}$ the $\boldsymbol{J}_{\boldsymbol{s c}}$ has value of 13.4 $\left(\mathrm{mA} / \boldsymbol{c m}^{2}\right)$ which is the optimized thickness of PEDOT:PSS as enhancement increased by $4.9 \%$ compared to thickness of 110 $\mathrm{nm}$ and by $2.2 \%$ compared to thickness $80 \mathrm{~nm}$

Table 1. The photocurrent density for different thickness of PEDOT:PSS layer with constant active layer thickness, $250 \mathrm{~nm}$

\begin{tabular}{|c|c|}
\hline PEDOT:PSS thickness & $\boldsymbol{J}_{\boldsymbol{s c}}\left(\mathbf{m A} / \mathbf{c m}^{\mathbf{2}}\right)$ \\
\hline $50 \mathrm{~nm}$ & 13.40 \\
\hline $80 \mathrm{~nm}$ & 13.11 \\
\hline $110 \mathrm{~nm}$ & 12.74 \\
\hline
\end{tabular}




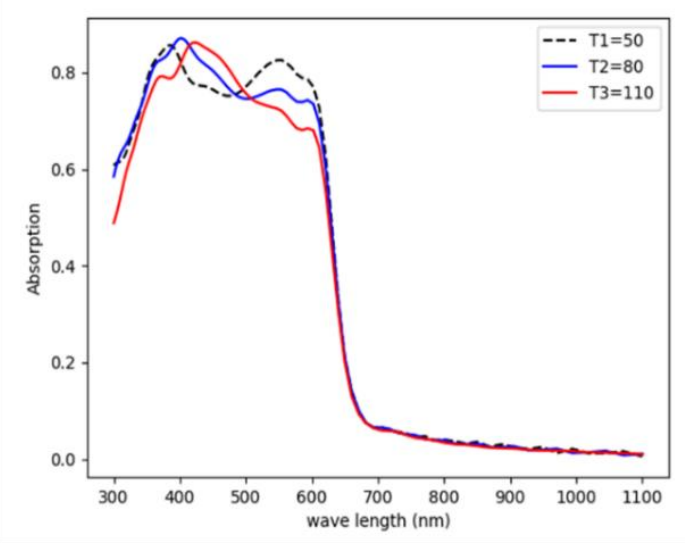

Fig 2. The absorption spectrum for different PEDOT:PSS layer thickness with constant active layer thickness, $250 \mathrm{~nm}$

Fig 3 represents the optical absorption curve of planner structure (without NPs). These data are achieved by using FDTD method and solving maxwell equations this curve shows that it has greater absorption values in the wavelength range between 350 $\mathrm{nm}$ and $650 \mathrm{~nm}$.

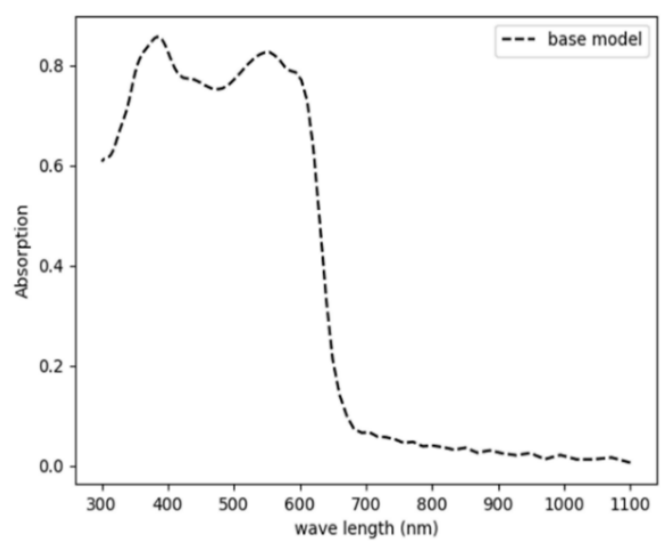

Fig 3. The aborption spectrum of the planner structure, OSC(A)

In order to trap light in the active layer to increase optical absorption and enhance PCE, we embedded a square periodic array of Au NPs with different sizes and shapes with lattice constant $70 \mathrm{~nm}$. Having NPs at different places such as the active layer or the buffer layer creates localized surface plasmon resonance (LSPR) which make NPs act as scattering centers for the incident light. Therefore, light is scattered with different angles, and this leads to elongate the optical paths hence more light is trapped and the optical absorption increases.

In our study we represent 6 configurations of OSC, deploying P3HT:BCPM as the active material. The proposed planar structure OSC(A) depicted in Fig 4 (a) was modified by having NPs in the active layer. The other configurations were achieved by embedding square periodic array of gold NPs of different shapes and sizes in the active layer such as nanospheres to obtain OSC(B) depicted in Fig 4(b), nanocylinder to obtain OSC(C) shown in Fig 4(c), nanocones to obtain OSC(D) shown in Fig 4(d), nanopyramids to obtain OSC(E) shown in Fig 4(e), and nanocubes to obtain OSC(F) shown in Fig 4(f).

\section{\IIIII}

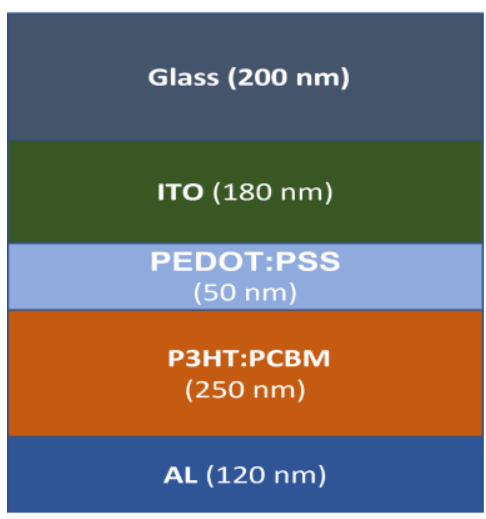

(a)
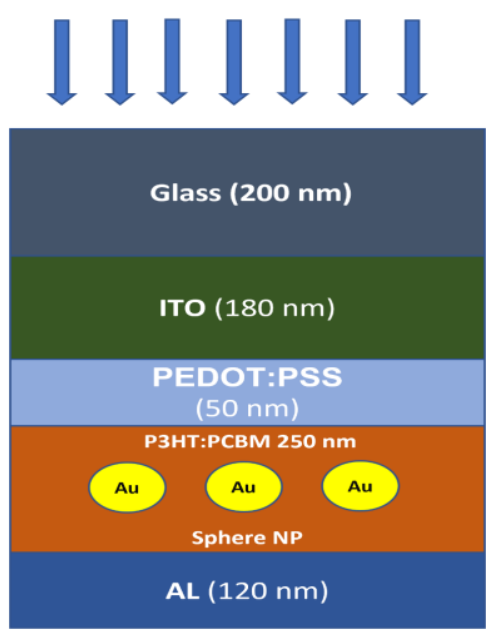

(b)

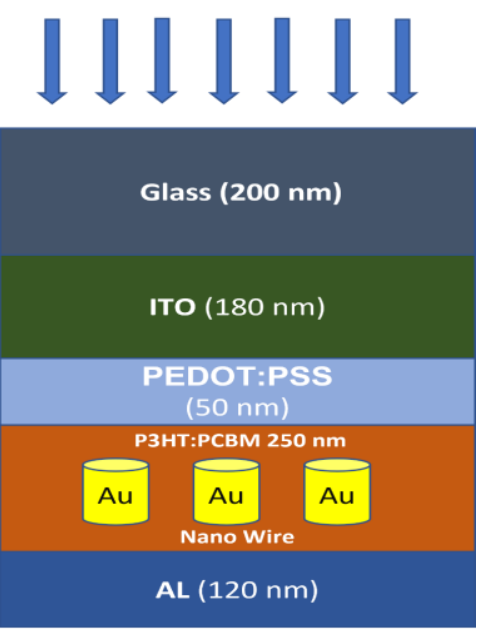

(c) 


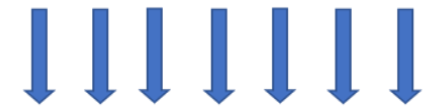

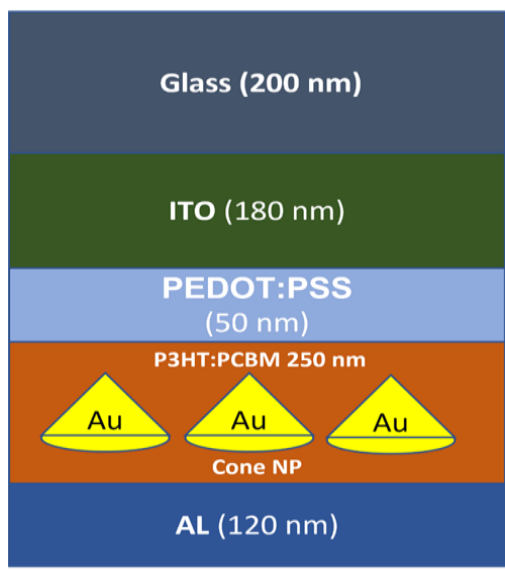

(d)
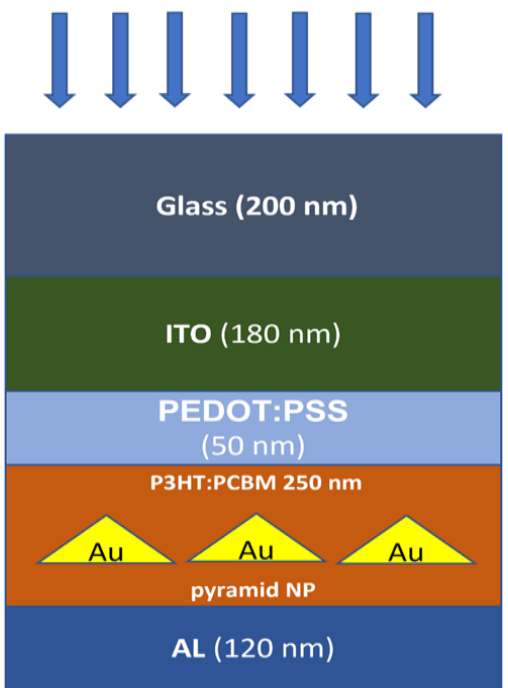

(e)
\IIII!

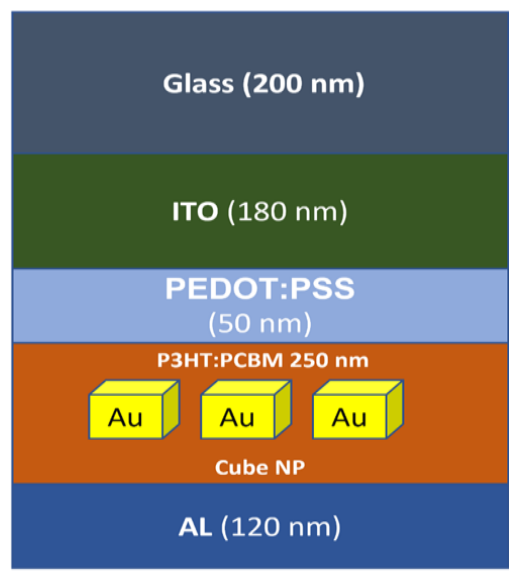

(f)

Fig 4. (a) planner structure OSC(A),(b) OSC(B)with spheres NPs, (c) OSC(C)with cylinder NPs. (d) OSC(D) with cones NPs, (e) OSC $(E)$ with pyramids NPs, $(f)$ OSC $(F)$ with cube NPs.

Table 2. The geometry parameters of NPs with different shapes

\begin{tabular}{|c|c|c|c|c|c|c|}
\hline & $\begin{array}{c}\text { Sphere } \\
\text { radius (r) } \\
\mathbf{n m}\end{array}$ & $\begin{array}{c}\text { Pyramid } \\
\text { height (h) } \\
\text { nm }\end{array}$ & $\begin{array}{c}\text { Cube side } \\
\text { length (L) } \\
\text { nm }\end{array}$ & $\begin{array}{c}\text { Cylinder } \\
\text { radius (x) } \\
\text { nm }\end{array}$ & $\begin{array}{c}\text { Cone } 1 \\
\text { height (c) } \\
\text { nm }\end{array}$ & $\begin{array}{c}\text { Cone } 2 \\
\text { Angle ( }(\boldsymbol{\theta})\end{array}$ \\
\hline Size (1) & 15 & 34.88 & 24.18 & 10.61 & 34.34 & $24.67^{\circ}$ \\
\hline Size (2) & 20 & 46.5 & 32.24 & 16.33 & 45.8 & $35.3^{\circ}$ \\
\hline Size (3) & 25 & 58.13 & 40.31 & 22.82 & 57.24 & $44.66^{\circ}$ \\
\hline Size (4) & 30 & 69.76 & 48.37 & 29.9 & 68.7 & $52.41^{\circ}$ \\
\hline
\end{tabular}

By embedding NPs in the active layer, the optical absorption enhanced by LSPR which make NPs as scattering medium so light rays will scatter with different angles so more light paths are generated and trapped so absorption increases. NPs were embedded with 4 different sizes and each size has 6 different shapes; they are all collected in the table 2.

In table 2, different volumes of NPs are used in the simulation as Size $(1)=14142.86 \mathrm{~nm}^{3}$, Size $(2)=33523.81 \mathrm{~nm}^{3}$, Size (3) $=$ $65476.2 \mathrm{~nm}^{3}$, and Size (4) $=113142.86 \mathrm{~nm}^{3}$. (r) indicates the radius of NPs sphere, (h) denotes the height of square pyramid, (L) indicates the side length of the cube, $(\mathrm{x})$ indicates the radius of cylinder as the height of cylinder is kept constant equal 40 $\mathrm{nm},(\mathrm{c})$ in cone 1 indicates the height of the cone as the angle is kept constant equal to $30^{\circ},(\Theta)$ in cone 2 indicates the angle of cone with the height is kept constant equal to $40 \mathrm{~nm}$.Fig 5 shows the absorption curves when the active layer is nanostructured with size (1), size (2), size (3), and size (4) for different NP shapes. It is noticed that we have enhancement of all absorption curves for all shapes compared to the base structure (without NPs). Some shapes have also higher degree of optical absorption compared to others. The pyramid NPs absorption spectrum is the highest among all other shapes including the base structure. 


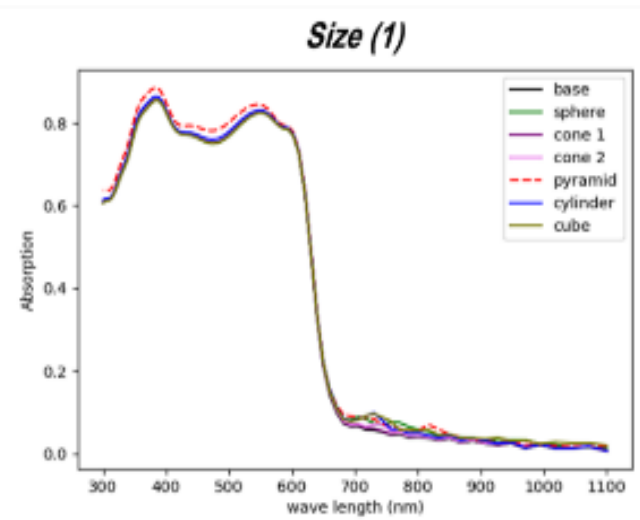

Size (3)

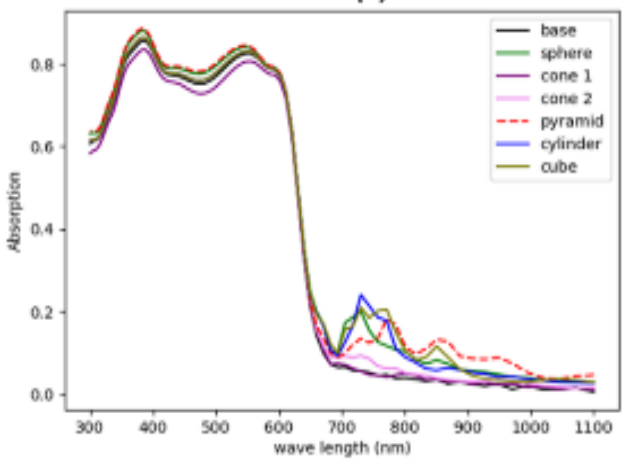

Size (2)

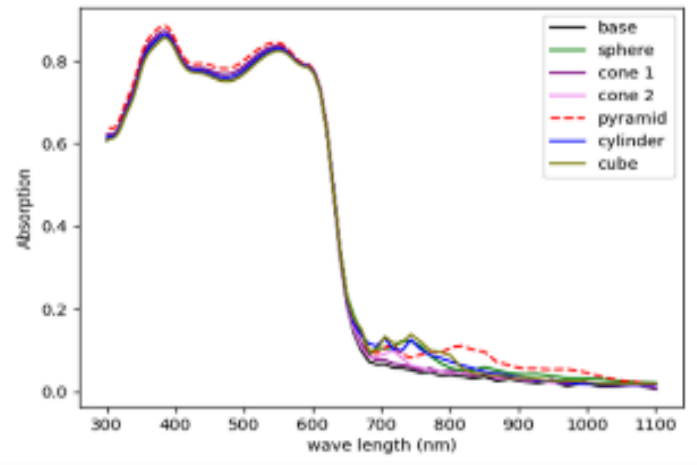

Size (4)

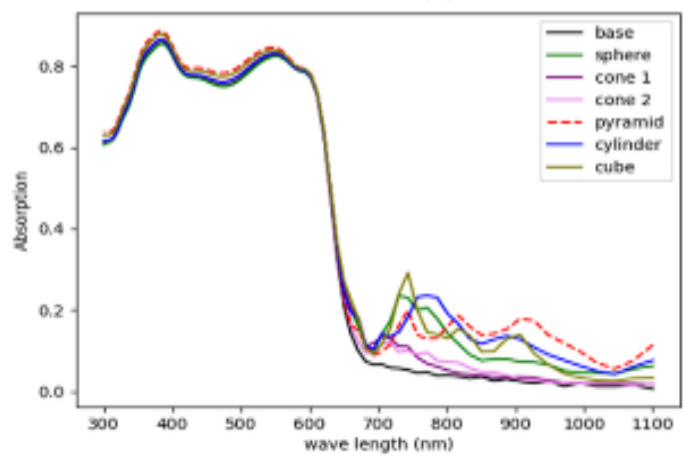

Fig 5. The aborption spectra for different nanoshapes for the same size.

As the size of NPs increase the optical absorption increases, all curves show enhancement in the wavelength range from $350 \mathrm{~nm}$ to $600 \mathrm{~nm}$. the photocurrent density was also affected and show different enhancement for different shapes and sizes, see Tables 3-8. The nanospheres introduced an improving of the photocurrent density up to $14.2 \%$ as shown in Table 3 while nanocubes introduced higher maximum as $17.1 \%$ as shown in Table 4. While in Table 5, nanocylinders introduced a maximum improvement of $18.4 \%$, nanopyramid introduced $20.3 \%$ in Table 6 , the best improvement of photocurrent density among all nanoshapes. In Tables 7 , increasing the nanocone height enhances $J_{S C}$ up to $5.8 \%$. The nanocone height is kept constant with changing the vertex angle. This results in an enhancement up to $5 \%$.

Table 3. The photocurrent density and the enhancement percentage compared to the base structure for nanospheres with different sizes

\begin{tabular}{|l|c|c|}
\hline \multicolumn{1}{|c|}{ Structure } & $\begin{array}{c}\boldsymbol{J}_{\text {sc }} \\
\left(\mathbf{m A} / \mathbf{c m}^{\mathbf{2}}\right)\end{array}$ & $\begin{array}{c}\text { Enhancement } \\
\text { Percentage (\%) }\end{array}$ \\
\hline Base structure & 13.40 & - \\
\hline Sphere size (1) & 13.73 & 6.5 \\
\hline Sphere size (2) & 14.22 & 12.2 \\
\hline Sphere size (3) & 15.03 & 14.2 \\
\hline Sphere size (4) & 15.30 & \\
\hline
\end{tabular}

Table 4. The photocurrent density and the enhancement percentage compared to the base structure for different size nanocubes

\begin{tabular}{|l|c|c|}
\hline Structure & $\begin{array}{c}\boldsymbol{J}_{\boldsymbol{s c}} \\
\left(\mathbf{m A} / \mathbf{c m}^{\mathbf{2}}\right)\end{array}$ & $\begin{array}{c}\text { Enhancement } \\
\text { Percentage (\%) }\end{array}$ \\
\hline $\begin{array}{l}\text { Base } \\
\text { structure }\end{array}$ & 13.40 & - \\
\hline $\begin{array}{l}\text { Cube size } \\
(1)\end{array}$ & 13.80 & 3 \\
\hline $\begin{array}{l}\text { Cube size } \\
(2)\end{array}$ & 14.13 & 5.5 \\
\hline $\begin{array}{l}\text { Cube size } \\
(3)\end{array}$ & 15.09 & 12. \\
\hline $\begin{array}{l}\text { Cube size } \\
(4)\end{array}$ & 15.69 & 17.1 \\
\hline
\end{tabular}


Table 5. The photocurrent density and the enhancement percentage compared to the base structure for different size nanocylinders

\begin{tabular}{|l|c|c|}
\hline Structure & $\begin{array}{c}\boldsymbol{J}_{\boldsymbol{s c}}(\mathbf{m A} \text { / } \\
\left.\mathbf{c m}^{\mathbf{2}}\right)\end{array}$ & $\begin{array}{c}\text { Enhancement } \\
\text { Percentage (\%) }\end{array}$ \\
\hline $\begin{array}{l}\text { Base } \\
\text { structure }\end{array}$ & 13.40 & - \\
\hline $\begin{array}{l}\text { Cylinder } \\
\text { size (1) }\end{array}$ & 13.74 & 2.6 \\
\hline $\begin{array}{l}\text { Cylinder } \\
\text { size (2) }\end{array}$ & 14.14 & 5.5 \\
\hline $\begin{array}{l}\text { Cylinder } \\
\text { size (3) }\end{array}$ & 14.88 & 11.6 \\
\hline $\begin{array}{l}\text { Cylinder } \\
\text { size (4) }\end{array}$ & 15.87 & 18.4 \\
\hline
\end{tabular}

Table 6. The photocurrent density and the enhancement percentage compared to the base structure for different size nanopyramids

\begin{tabular}{|l|c|c|}
\hline \multicolumn{1}{|c|}{ Structure } & $\begin{array}{c}\boldsymbol{J}_{\boldsymbol{s c}}(\mathbf{m A} / \\
\left.\mathbf{c m}^{\mathbf{2}}\right)\end{array}$ & $\begin{array}{c}\text { Enhancement } \\
\text { Percentage } \\
(\%)\end{array}$ \\
\hline Base structure & 13.40 & - \\
\hline Pyramid size (1) & 14.07 & 5 \\
\hline Pyramid size (2) & 14.72 & 9.8 \\
\hline Pyramid size (3) & 15.32 & 14.4 \\
\hline Pyramid size (4) & 16.12 & 20.3 \\
\hline
\end{tabular}

The photocurrent density $\left(J_{s c}\right)$ varies from size to size and from shape to shape in the same size, in general as the size of NPs increases, we get enhancement of $J_{s c}$. In case of pyramid NPs, we have the best absorption curve and hence the highest $J_{s c}$ compared to the other shapes. In case of cone 2 shape with constant height $40 \mathrm{~nm}$, we obtain the lowest enhancement of $J_{s c}$ since the optical absorption is low in this case. An important note in these results obtained from cone 1 and cone 2 shapes is that varying shapes of NPs gives different result as
Table 7. The photocurrent density and the enhancement percentage compared to the base structure for nanocones with constant theta $30^{\circ}$ and variable height.

\begin{tabular}{|l|c|c|}
\hline \multicolumn{1}{|c|}{ Structure } & $\begin{array}{c}\boldsymbol{J}_{\boldsymbol{s c}}(\mathbf{m A} / \\
\left.\mathbf{c m}^{\mathbf{2}}\right)\end{array}$ & $\begin{array}{c}\text { Enhancement } \\
\text { Percentage } \\
(\boldsymbol{\%})\end{array}$ \\
\hline Base structure & 13.40 & - \\
\hline Cone 1 size (1) & 13.47 & 0.5 \\
\hline Cone 1 size (2) & 13.76 & 2.7 \\
\hline Cone 1 size (3) & 14 & 4.5 \\
\hline Cone 1 size (4) & 14.17 & 5.8 \\
\hline
\end{tabular}

Table 8. The photocurrent density and the enhancement percentage compared to the base structure for nanocones with constant height $40 \mathrm{~nm}$ and variable vertex angle

\begin{tabular}{|l|c|c|}
\hline \multicolumn{1}{|c|}{ Structure } & $\begin{array}{c}\boldsymbol{J}_{\text {sc }} \\
\left(\mathbf{m A} / \mathbf{c m}^{\mathbf{2}}\right)\end{array}$ & $\begin{array}{c}\text { Enhancement } \\
\text { Percentage } \\
(\%)\end{array}$ \\
\hline Base structure & 13.40 & - \\
\hline Cone 2 size (1) & 13.60 & 1.5 \\
\hline Cone 2 size (2) & 13.72 & 2 \\
\hline Cone 2 size (3) & 13.85 & 3.4 \\
\hline Cone 2 size (4) & 14.07 & 5 \\
\hline
\end{tabular}

both are cones but changing some parameter relative to the other in the same shape gives different optical absorption and hence different $J_{s c}$. 


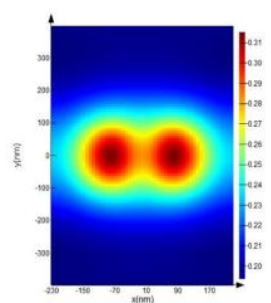

Sphere

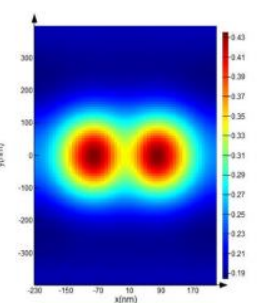

Cylinder

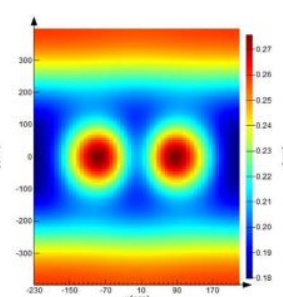

Pyramid

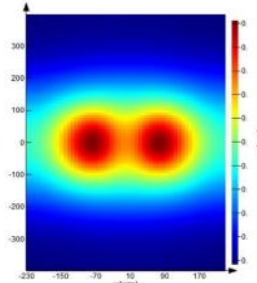

Cube

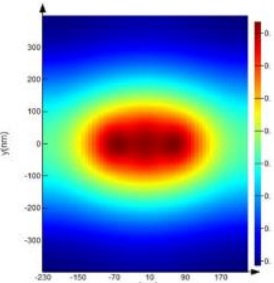

Cone 1

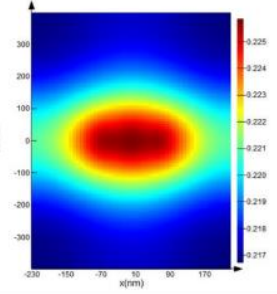

Cone 2

Fig 6. The electric field distribution in the active layer surrounding the same size NPs for different shapes

Fig 6 depicts the distribution of electric field by simulation monitor for different shapes at the same size. It is noticed that some shapes distribute electric filed around them higher than the others and this is the reason why different shapes have different optical absorption and hence photocurrent density although they have the same size. The most interesting distribution is that for the nanopyramid whose scattering was the highest among all NPs shape.

\section{Conclusions}

The optical absorption and photocurrent density enhancement were studied for possible plasmonic enhancement. Gold nanoparticles are embedded in the active area of the proposed structure. In house 3D FDTD software were used in simulation to study the impact of the nanoparticles with various sizes and shapes. For instance, we get $J_{s c}$ of $15.3 \mathrm{~mA} / \mathrm{cm}^{2}$ and enhancement percentage of $14.2 \%$ compared to the planner structure for nanospheres with radius $30 \mathrm{~nm}$. Also, we obtained $J_{s c}$ of $15.69 \mathrm{~mA} / \mathrm{cm}^{2}$ and enhancement percentage of $17.1 \%$ with cube length of $48.37 \mathrm{~nm}$.

The nanocone gave the best enhancement at vertex angle of $\Theta=30^{\circ}$ and height of $68.7 \mathrm{~nm}$. For nanocylinders, radius $=40 \mathrm{~nm}$ and

height $29.9 \mathrm{~nm}$ results in the best improvement. We may conclude that, among all shapes of NPs the best shape is pyramidal which leads to a photocurrent density of $16.12(\mathrm{~mA} /$ $\mathrm{cm}^{2}$ ) and enhancement percentage of $20.3 \%$ compared to the base structure.

\section{References}

[1] H.L. Huang, C.T. Lee, H.Y. Lee, Performance improvement mechanisms of P3HT: PCBM inverted polymer solar cells using extra PCBM and extra P3HT interfacial layers. Org. Electron. 21,126-131,2015.

[2] Dan Chi, Shengchun Qu, Zhanguo Wang and Jizheng Wang, High efficiency P3HT:PCBM solar cells with an inserted PCBM layer, J. Mater. Chem. C, 2, 4383, 2014.

[3] S. Y. Chang, P. Cheng, G. Li and Y. Yang, Joule, Transparent polymer photovoltaics for solar energy harvesting and beyond, , 2, 1039-1054,2018.
[4] Anjusree S., Arya K. R. and Bikas C. Das" Air-processed active-layer of organic solar cells investigated by conducting AFM for precise defect detection" RSCAdv., 10, 24882, 2020.

[5] J. Y. Zhou, X. J. Wan, Y. S. Liu, G. K. Long, F. Wang, Z. Li,Y. Zuo, C. X. Li and Y. S. Chen" A bipolar small molecule based on indacenodithiophene and diketopyrrolopyrrole for solution processed organic solar cells" Chem. Mater., 23,4666-4668, 2011.

[6] Hongkyu Kang, Geunjin Kim, Junghwan Kim, Sooncheol Kwon, Heejoo Kim, and Kwanghee Lee, BulkHeterojunction Organic Solar Cells: Five Core Technologies for Their Commercialization"Adv. Mater., 287821$7861,2016$.

[7] B. Siegmund, M. T. Sajjad, J. Widmer, D. Ray, C. Koerner,M. Riede, K. Leo, I. D. W. Samuel and K. Vandewal," Exciton Diffusion Length and Charge Extraction Yield in Organic Bilayer Solar Cells" Adv.Mater., , 29, 1604424,2017

[8] V. Shrotriya, G. Li, Y. Yao, C. W. Chu and Y.Yang," Transition metal oxides as the buffer layer for polymer photovoltaic cells"Appl. Phys. Lett., 88, 073508,2006.

[9] A. Tada, Y. F. Geng, Q. S. Wei, K. Hashimoto and K. Tajima," Tailoring organicheterojunction interfaces in bilayer polymer photovoltaic devices"Nat. Mater., 10, 450455, 2011.

[10] B. Kadem, W. Cranton, A. Hassan, Metal salt modified PEDOT:

PSS as anode buffer layer and its effect on power conversion efficiency of organic solar cells. Org. Electron. 24, 73-79 ,2015.

[11] Barbara Paci, Amanda Generosi,a Valerio Rossi Albertini, George D. Spyropoulos, Emmanuel Stratakis and Emmanuel Kymakis" Enhancement of photo/thermal stability of organic bulk heterojunction photovoltaic devices via gold nanoparticles doping of the active layer $\dagger$ " Nanoscale, 4, 7452,2012 .

[12] Peng Xu, Liang Shen, Fanxu Meng, Jiaqi Zhang, Wenfa Xie, Wenjuan Yu, Wenbin Guo, Xu Jia, and Shengping Ruan" The role of Ag nanoparticles in inverted polymer solar cells: Surface plasmon resonance and backscattering centers" APPLIED PHYSICS LETTERS 102, 123301, 2013.

[13] Zhihai Liu, Seung Yong Lee, and Eun-Cheol Lee," Copper nanoparticle incorporated plasmonic organic bulk- 
heterojunction solar cells" APPLIED PHYSICS LETTERS 105, 223306, 2014.

[14] Eng Liang Lim, Chi Chin Yap, Mohd Asri Mat Teridi, Chin Hoong Teh, Abd Rashid bin Mohd Yusoff, Mohammad Hafizuddin Hj Jumali " A review of recent plasmonic nanoparticles incorporated P3HT: PCBM organic thin film solar cells" E.L. Lim et al., Organic Electronics 36,2016.
[15] Zahra Arefinia and Dip Prakash Samajdar" Novel semi-analytical

optoelectronic modeling based on homogenization theory for realistic plasmonic polymer solar cells" Scientific Reports, Vol.:(0123456789), 11:3261, 2021.

[16] Lin Feng, Mengsi Niu, Zhenchuan Wen and Xiaotao Hao, "Recent Advances of Plasmonic Organic Solar Cells: Photophysical Investigations" Polymers, 10, 123, 2018. 